\title{
TRANSACTIONS IN LAND IN THE SUBURBAN ZONE OF BYDGOSZCZ OVER THE YEARS 2007-2010
}

\author{
Benicjusz GŁęBOCKI ${ }^{1}$, Robert Perdą ${ }^{2}$ \\ ${ }^{1}$ Institute of Architecture, Construction and Spatial Economy, University of Economy, Bydgoszcz, Poland \\ ${ }^{2}$ Institute of Socio-Economic Geography and Spatial Management, Adam Mickiewicz University, Poznań, \\ Poland
}

Manuscript received: May 14, 2013

Revised version: July 22, 2013

\begin{abstract}
GŁęBOCKi B., Perdat R., 2013. Transactions in land in the suburban zone of Bydgoszcz over the years 2007-2010. Quaestiones Geographicae 32(4), Bogucki Wydawnictwo Naukowe, Poznań, pp. 103-116, 5 figs, 5 tables. DOI 10.2478/quageo-2013-0037, ISSN 0137-477X.
\end{abstract}

ABSTRACT: This article offers a spatial analysis of transactions in land seen against the resources of land and its use pattern in the Bydgoszcz suburban zone over the years 2007-2010. The research covered individual transactions aggregated into geodetic precincts by type of land. Its object was the most popular types of land, viz. farmland, built and unbuilt urbanised land, and recreational land. The analysis embraced the number of sale/purchase transactions concluded, the mean area of lots, and their market value.

KEY WORDS: land-use pattern, agricultural land, built land, unbuilt land, recreational land, sale/purchase transactions, market value

Benicjusz Gtębocki, Robert Perdat, Institute of Socio-Economic Geography and Spatial Management, Adam Mickiewicz University, ul. Dzięgielowa 27, 61-680 Poznań, Poland; e-mail: beni@amu.edu.pl, r.perdal@amu.edu.pl

\section{Introduction}

The aim of this paper is to analyse spatial aspects of the land market in areas adjacent to a big city. In the suburban zones of such cities in Poland this market displays a number of specific features. Transactions usually involve lots that are small in area, but of high market value. After the ownership rights have been transferred, there is a change in the old use of the land. It is mainly earmarked for single-family residential construction, often combined with services that are not too burdensome. The buyers are mainly natural persons, usually residents of a region's biggest city; less frequently, developer companies.
The suburban zone of Bydgoszcz city dealt with in the present paper was limited to the administrative boundaries of Bydgoszcz poviat (the city constituting a poviat in itself), mainly for formal reasons, especially the availability of data concerning land turnover. This limitation is partly justified by the zone's commuting rate.

As a rule, the land market in suburban zones is highly specific. In the area under study, this specificity is additionally enhanced by the location of Bydgoszcz and the city's spatial development as determined by those geographical conditions. Bydgoszcz poviat is part of two large physical-geographic regions: the Świecie Upland and the Torun Basin, separated by the valley of the Brda river, which in turn is part of the 
Torun-Eberswald Pradolina, the Lower Vistula Valley, and the Chełm-Dobrzyń Lakeland (Kondracki 1994, 2009).

The analysis of land transactions in Bydgoszcz poviat was conducted at the level of geodetic precincts (Fig. 1) ${ }^{1}$.

Bydgoszcz was incorporated as a town relatively late, receiving 'Magdeburg rights' in 1346. Initially, its spatial development was mainly connected with the mouth section of the Brda valley. It was only after the Second World War that intensive urbanisation processes made the city spread wider, chiefly up the Brda valley and along the Bydgoszcz Canal' ${ }^{2}$. When Fordon', formerly a separate town, was joined to Bydgoszcz in 1973, urbanisation embraced the surroundings of the Fordon Valley. In Bydgoszcz itself, intensive development has been limited mainly by its natural conditions, which means that it has ever fewer empty lots to build on within the present administrative limits. The city is surrounded on all sides by natural barriers which make its free spatial development difficult, if not impossible. The barrier from the east is the Vistula, those from the remaining directions are large forest complexes intruding into its administrative area. In almost all cadastral districts urbanised areas have reached the boundary of woodland. Hence new buildings are constructed mainly in the city's peripheral areas situated higher up in the Fordon Valley. Even so, in this part of the city, too, the spatial expansion of urbanisation is limited by the Lower Vistula Valley Landscape Park, and from the east, by the marshy expanses of the Vistula valley. In the remaining areas, connected mainly with the Brda valley and the Bydgoszcz Canal, one can only observe a steady increase in the density of building, or the location of new investment on land so far chaotically built up with

1 A geodetic precinct is a unit area in the division of the country established for the purposes of land and buildings registration (Land and Buildings Registration Ordinance of the Ministry of Regional Development and Construction of 29 March 2001, Official Gazette no. 38, position 454).

2 It is the oldest navigable canal in Poland. Opened in 1774, it connects the Vistula and Brda rivers with the Noteć.

3 It received municipal rights in 1424, and derived its name (from English) from the customs duty and water tax it collected in the medieval times. all kinds of depreciated constructions ${ }^{4}$. Those are also areas where revitalisation, often extensive, is conducted. Those processes are slow for a variety of reasons, but they systematically restore spatial order to the old building pattern of Bydgoszcz.

The factors confining Bydgoszcz in its spatial development, shortly outlined above, have caused urbanisation processes to exceed the city limits because its resources of unbuilt land that might be of interest to investors are scarce. This is corroborated by an analysis of land turnover in the city over the years 2007-2009 (Głębocki 2011), a short time interval already partly marked by the world economic crisis. For this reason the analysis of land sale/purchase transactions concluded at that time only allowed preliminary conclusions of a strategic nature concerning the city's further spatial development. Still, even this study revealed the scale of land turnover and the level of land prices within the city. It also identified regularities in the spatial development of urbanisation processes in Bydgoszcz. However, at this stage of the research there were no data that would allow an analysis of land turnover in its suburban zone. That is why it was decided to continue similar studies covering the entire Bydgoszcz poviat. The analysis embraced land sale/purchase transactions made here in the years 2007-2010.

While transactions in the city involved almost exclusively arable land and unbuilt construction sites, in the poviat the diversity of land lots traded was greater. Between 2007 and 2009, the transactions in Bydgoszcz embraced 82.3 ha of agricultural land, mainly arable, and 63.7 ha of vacant construction lots. Those were small plots, only in single cases exceeding 1 hectare in area. In the poviat, however, in the case of farmland, those were multi-hectare transactions, while the smallest lots traded were built-up ones, usually with single-family housing. Over the years 2007-2010 the sale/purchase transactions in the poviat embraced 1,902.8 ha of farmland, 144.6 ha of unbuilt construction lots, 70.5 ha of land with single-family houses, and 79.7 ha of recreational land ${ }^{5}$.

In the years 2007-2010 land turnover in Bydgoszcz poviat brought about marked changes in

$4 \quad$ Those are usually all kinds of sheds and other storage facilities, many of which have lost their old functions. 5 Those area-related figures do not concern registered transactions with incomplete documentation. 


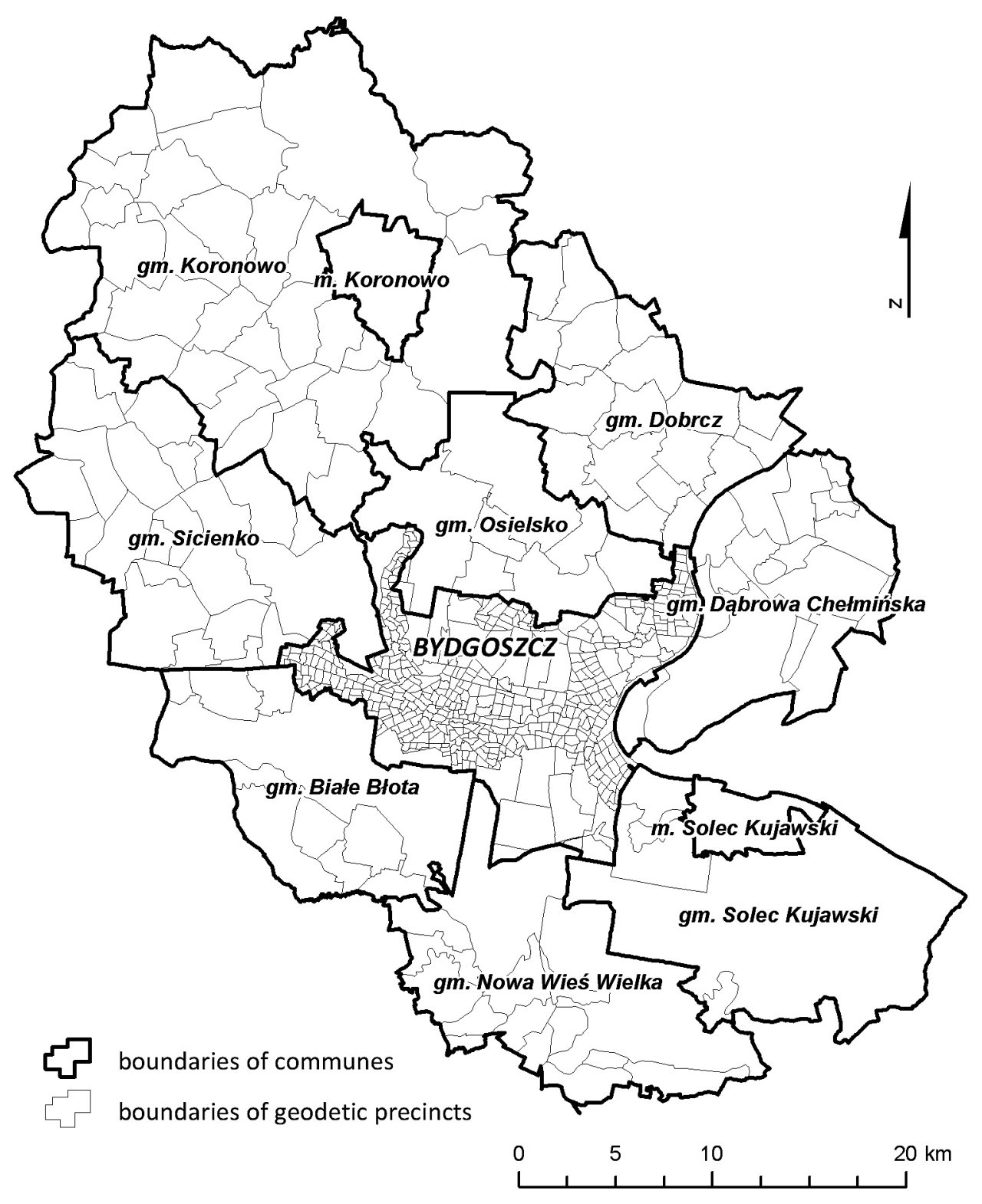

Fig. 1. Administrative division of Bydgoszcz poviat.

the land-use pattern. The largest share of transactions involved agricultural land. However, only some of it was intended for farm enlargement; most was bought for other purposes, mainly residential, as indicated by the area of individual lots, only rarely exceeding $3,000 \mathrm{~m}^{2}$. One of the measurable effects of those transactions was an increase in the proportion of plots of land not exceeding 1 ha and not being part of agricultural holdings. The area of this category of land grew by $20.5 \%$ over the study period (to $1,328 \mathrm{ha}$, as of the end of 2010). Those were mostly lots originally in agricultural use which changed their purpose just before or after the sale, usually to the residential one. A substantial group of transactions concerned vacant land intended for residential construction, as well as built-up and recreational land. The volume of those transactions and their spatial range, as in the suburban zones of Poland's other big cities, resulted from a steady advance of urbanisation processes.

What gives the spatial development of urbanisation in the suburban zone of Bydgoszcz a specific character is the region's high woodiness index. In 2011 forests and shrub-grown land occupied $42.6 \%$ of the poviat area, while in the communes surrounding the city this figure as a rule exceeded $50 \%$. The index was the highest in two com- 
Table 1. Selected forms of land use in Bydgoszcz poviat (as of 1 January 2011).

\begin{tabular}{|c|c|c|c|c|c|c|c|c|c|}
\hline \multirow{3}{*}{ Towns, communes } & \multirow{3}{*}{$\begin{array}{c}\text { Total } \\
\text { area }\end{array}$} & \multicolumn{8}{|c|}{ of which } \\
\hline & & \multicolumn{2}{|c|}{ agricultural land } & \multicolumn{2}{|c|}{$\begin{array}{l}\text { woodland and } \\
\text { shrub-grown land }\end{array}$} & \multicolumn{2}{|c|}{$\begin{array}{l}\text { urbanised and } \\
\text { built-up land }\end{array}$} & \multicolumn{2}{|c|}{$\begin{array}{c}\text { plots of land up } \\
\text { to } 1 \text { ha }\end{array}$} \\
\hline & & ha & $\%$ & ha & $\%$ & ha & $\%$ & ha & $\%$ \\
\hline Towns, total & 4,666 & 1,926 & 41.3 & 1,286 & 27.6 & 1,009 & 21.6 & 582 & 12.5 \\
\hline Koronowo, town & 2,809 & 1,171 & 41.7 & 861 & 30.7 & 489 & 17.4 & 288 & 10.3 \\
\hline Solec Kujawski, town & 1,857 & 755 & 40.7 & 425 & 22.9 & 520 & 28.0 & 294 & 15.8 \\
\hline Rural communes, total & 134,393 & 61,509 & 45.8 & 57,906 & 43.1 & 7,134 & 5.3 & 5,757 & 4.3 \\
\hline Białe Błota & 12,209 & 3,359 & 27.5 & 6,650 & 54.5 & 1,435 & 11.8 & 1210 & 9.9 \\
\hline Dąbrowa Chełmińska & 12,408 & 5,080 & 40.9 & 5,975 & 48.2 & 569 & 4.6 & 828 & 6.7 \\
\hline Dobrcz & 12,938 & 10,393 & 80.3 & 983 & 7.6 & 814 & 6.3 & 645 & 5.0 \\
\hline Koronowo Wieś & 38,288 & 21,582 & 56.4 & 12,269 & 32.0 & 1,407 & 3.7 & 853 & 2.2 \\
\hline Nowa Wieś Wielka & 14,790 & 3,938 & 26.6 & 9,380 & 63.4 & 810 & 5.5 & 545 & 3.7 \\
\hline Osielsko & 10,167 & 2,970 & 29.2 & 6,009 & 59.1 & 926 & 9.1 & 902 & 8.9 \\
\hline Sicienko & 17,931 & 12,486 & 69.6 & 3,626 & 20.2 & 888 & 5.0 & 644 & 3.6 \\
\hline Solec Kujawski, village & 15,662 & 1,701 & 10.9 & 13,014 & 83.1 & 285 & 1.8 & 130 & 0.8 \\
\hline Bydgoszcz poviat & 139,060 & 63,435 & 45.6 & 59,192 & 42.6 & 8,143 & 5.9 & 6,339 & 4.6 \\
\hline
\end{tabular}

Source: Land register in Bydgoszcz poviat as of 1 January 2011. Voivodeship Centre for Geodetic and Cartographic Documentation in Włocławek.

munes in the south: Nowa Wieś Wielka (63.4\%) and Solec Kujawski (83.1\%). The woods growing there are the southern part of an extensive woodland complex known as the Bydgoszcz Forest. Only Sicienko commune has a lower woodiness index $(20.2 \%)$, but it is separated from the city by an extensive forest complex. Hence urbanisation processes are the most intense along traditional transport routes and in areas situated on the Świecie Upland, readily accessible to Bydgoszcz residents and lying outside the woodland zone.

The land which interests investors the most is that in Białe Błota commune and partly in Nowa Wieś Wielka commune, situated in the Torun Basin and adjacent to Bydgoszcz from the south and west. The animated land turnover in the communes surrounding Bydgoszcz, especially those in the north and south-west, contributes to the disappearance of farming in rural areas. It is being replaced by other functions, especially residential, service and recreational ones.

Those processes, no doubt, are reinforced indirectly by modest resources of farmland in the study area, especially arable land, that could be of interest to the land market. Among the communes neighbouring on Bydgoszcz, the one with major resources of agricultural land is Sicienko. However, because of its poor transport connections with the city and the extensive forest complex that separates them, the farmland of this commune does not attract much interest of potential buyers of land for investment. That is why, despite its favourable location with respect to Bydgoszcz, only 80 transactions were completed here in the study period, of which as many as $62(77.5 \%)$ involved agricultural land. Some of those transactions were conducted to enlarge farms. However, even less interest in this respect was shown to the most woody commune in Bydgoszcz poviat, Solec Kujawski (its rural area), in which a mere 24 transactions were made.

What control the land market in Bydgoszcz poviat, like other markets of this type, are not only natural assets, location with respect to the central city, and good transport links with it, but also prices, financial resources, especially of the city residents, and the socio-economic situation of the country. Another factor that greatly affected the volume of land turnover was also the current economic crisis. Over the study period the biggest number of transactions were concluded in 2007, and the fewest, in 2009. While there were 955 transactions (39.9\%) in the three most important land categories (agricultural, unbuilt and built-up) in Bydgoszcz poviat in 2007, in 2009 this figure dropped to a mere 405 (19.7\%). The proportions of the market value of land in those transactions followed a similar pattern. The year 2010 saw a slight upswing on the land market, but the number of transactions concluded and the market value of land sold did not reach the 2007 and 2008 levels. For lack of information, one 
cannot be sure whether the observed tendency is going to prevail.

\section{Land use in the suburban zone}

The development of the land market in Bydgoszcz poviat - its present spatial range - has led to the appearance of clearly marked areas of accelerated urbanisation processes whose centres are administrative seats of communes with well-developed physical infrastructure and ensuring its residents basic material and non-material services (Fig. 1).

A spatial manifestation of this process is the belt of highly urbanised villages that surround Bydgoszcz, either directly adjacent to the city or situated beyond the forest zone, but well-connected with it by transport. This phenomenon is illustrated in Fig. 2, which presents the density of land lots under 1 ha in area owned by natural persons who do not operate agricultural holdings. The lower proportion of this category of land in areas directly neighbouring on Bydgoszcz is due to the extensive forest complexes growing there, while in the village of Białe Błota an additional factor is a low-lying fragment of the Torun-Eberswald Pradolina where hydrographic conditions are unfavourable to residential construction. Besides, housing estates usually occupy a small area, which pushes the value of the index in question still further down, given the high woodiness and 'bogginess' levels of the village.

This is a convenient point to note that urbanisation started very early in Białe Błota village, so at present the best free lots for construction have already been taken. At the same time one can observe here an almost complete disappearance of the farming function. It is perhaps for this reason that a mere 16 transactions in agricultural land were concluded in the village over the study period, which is a very modest figure when compared against the number of transactions in builtup (71) and unbuilt land (74).

Worth noting is the fact that in seven rural settlements the proportion of lots of less than 1 ha exceeded $20 \%$ of their total area. All of them are located in the suburban zone of Bydgoszcz. Four (Łochowice, Łochowo, Murowanie and Przyłęcki) lie in Białe Błota commune and two

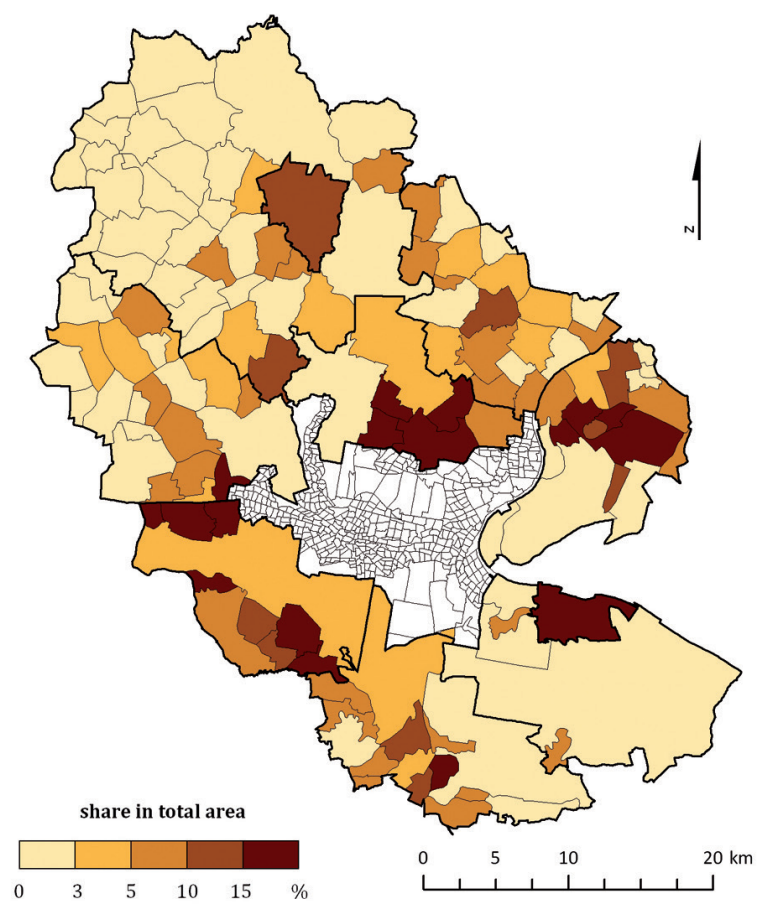

Fig. 2. Plots of land under 1 ha belonging to natural persons that are not part of agricultural holdings, 2010

(Niemcz and Osielsko) in Osielsko commune. For reasons given earlier, in the village of Białe Błota this category of land occupied a total of 209 ha, which is a mere $3.2 \%$ of its area.

The percentage of such lots is the smallest in the peripheries of the poviat. Those are agricultural areas with a high proportion of woodland and poor transport links with Bydgoszcz. In the heavily forested areas surrounding Bydgoszcz, the settlement units located there are small. They usually occupy mid-forest clearings with no possibility of spatial development. An example is the village of Bożenkowo in Osielsko commune.

\section{Transactions in agricultural land}

The land market is variously defined depending on the entities involved, but the definitions also embrace the whole of relationships holding between the parties to exchange transactions (Brzeski et al. 2008). Also, its object of exchange has two specific characteristics: immobility and a spatial nature. The land market in the suburban zone of Bydgoszcz, while local, is shaped by similar, and similarly diverse, factors as those controlling more extensive spatial markets. This diversity of factors moulding the land market is 
emphasised by all the authors dealing with this issue, e.g. Kucharska-Stasiak (1999), Kałkowski (2003), Niemczyk (2002), Cymerman and Hopfer (2005), Hozer (2006), Maćkiewicz (2007), Źróbek et al. (2008), and Jakóbczyk-Gryszkiewicz (2009).

Over the years 2007-2010, the biggest number of transactions concluded in the study area concerned agricultural land. There were 1,075 of them involving a total of $19,028,000 \mathrm{~m}^{2}$, and their market value amounted to $178,861,000$ zlotys (Table 2 ). The objects were mainly small plots of farmland, as a rule conforming to the size standards for lots intended for single-family housing. Their area usually did not exceed $3,000 \mathrm{~m}^{2}$. In transactions involving farmland, lots up to 1 ha in area made up $85.8 \%$. The number of big transactions, concerning lots of 5 ha and more, was small. Usually this was land bought to enlarge already existing farms. On rare occasions entire agricultural holdings were sold. Hence the market value of 1 $\mathrm{m}^{2}$ of land varied widely. Agricultural land had the highest value in the villages of two communes located attractively in relation to Bydgoszcz: Białe Błota and Osielsko. Out of the 192 transactions in agricultural land conducted over the study period in which the market value of $1 \mathrm{~m}^{2}$ exceeded 100 zlotys, as many as 141 (75.5\%) concerned land in those two communes, especially in the villages of Białe Błota, Niemcz and Osielsko, where the value of farmland attained very high prices in several transactions, more than 1,000 zlotys per $\mathrm{m}^{2}$, while the area of those lots ranged from 430 to $1,530 \mathrm{~m}^{2}$. The high prices obtained for agricultural land in those villages were due not only to the factors mentioned earlier, but also to the mentality of the buyers, and even their speculative approach. Some of the lots fetching high prices were built up, but in most cases the buildings were old, in need of repair or only fit for demolition.

Apart from the above-mentioned communes, major transactions in agricultural land were performed in the communes of Dobrcz, Koronowo and Nowa Wieś Wielka. Their objects differed. In Koronowo commune they usually involved large lots intended for agricultural purposes. Their average size exceeded 5 ha (in single cases the land bought exceeded 40 or even 80 ha), but their market value was the lowest in entire Bydgoszcz poviat (Table 2). In the other two communes the size of lots varied. Predominant among them were smaller ones, only rarely exceeding $10 \mathrm{ha}$, but there were single cases of big transactions. The largest - 86.8 ha - was concluded in the village of Kobylarnia (Nowa Wieś Wielka commune).

The largest transactions were usually performed in areas with ample resources of land left by former state farms or agricultural cooperatives, usually situated in the periphery of the poviat, and now Treasury property, although there were also large transactions in which the sellers were natural persons. In such large transactions (exceeding $10 \mathrm{ha}$ ) the farmland market value was

Table 2. Transactions in agricultural land in Bydgoszcz poviat over the years 2007-2010.

\begin{tabular}{|c|c|c|c|c|c|c|c|c|}
\hline \multirow{2}{*}{$\begin{array}{l}\text { Towns, } \\
\text { communes }\end{array}$} & \multicolumn{2}{|c|}{ Transactions, total } & \multicolumn{2}{|c|}{ Total market value } & \multicolumn{2}{|c|}{ Total area } & \multirow{2}{*}{$\begin{array}{c}\text { Mean size } \\
\mathbf{m}^{2}\end{array}$} & \multirow{2}{*}{$\begin{array}{c}\begin{array}{c}\text { Mean } \\
\text { price }\end{array} \\
\text { zlotys } / \mathrm{m}^{2}\end{array}$} \\
\hline & number & $\%$ & $\begin{array}{l}\text { thous. } \\
\text { zlotys }\end{array}$ & $\%$ & thous. $\mathrm{m}^{2}$ & $\%$ & & \\
\hline Bydgoszcz poviat & 1,075 & 100.0 & 178,861 & 100.0 & 19,028 & 100.0 & 17,700 & 9 \\
\hline Towns, of which: & 82 & 7.6 & 13054 & 7.3 & 420 & 2.2 & 5,121 & 31 \\
\hline Koronowo, town & 22 & 2.0 & 1963 & 1.1 & 157 & 0.8 & 7,134 & 13 \\
\hline Solec Kuj., town & 60 & 5.6 & 11,091 & 6.2 & 263 & 1.4 & 4,382 & 42 \\
\hline Communes: & 993 & 92.4 & 165,807 & 92.7 & 18,608 & 97.8 & 18,739 & 8 \\
\hline Białe Błota & 233 & 21.7 & 36,496 & 20.4 & 1,833 & 9.6 & 7,869 & 20 \\
\hline Dąbrowa Chełm. & 70 & 6.5 & 4,757 & 2.7 & 832 & 4.4 & 11,879 & 6 \\
\hline Dobrcz & 157 & 14.6 & 20,766 & 11.6 & 2,185 & 11.5 & 13,915 & 10 \\
\hline Koronowo & 140 & 13.0 & 17,205 & 9.6 & 7,241 & 38.1 & 51,724 & 2 \\
\hline Nowa Wieś Wlk. & 102 & 9.5 & 10,424 & 5.8 & 3,438 & 18.1 & 33,705 & 3 \\
\hline Osielsko & 205 & 19.1 & 66,306 & 37.1 & 1,928 & 10.1 & 9,407 & 34 \\
\hline Sicienko & 62 & 5.8 & 7,566 & 4.2 & 745 & 3.9 & 12,027 & 10 \\
\hline Solec Kujawski & 24 & 2.2 & 2,287 & 1.3 & 405 & 2.1 & 16,874 & 6 \\
\hline
\end{tabular}

Source: Own compilation on the basis of reports from the price register for experts of the Department of Geodesy and Cartography of the Poviat Office in Bydgoszcz. 
usually 1-2 zlotys, or even under 1 zloty, per $\mathrm{m}^{2}$. This low price was not only due to its area and purpose, but also to a family situation of the parties involved, or other non-market factors. Most of those transactions were made in 2007. In the next years the size of the farmland lots sold was smaller, although in single cases their area exceeded 40 ha. The highest number of large agricultural transactions were completed in the rural commune of Koronowo; in the remaining ones only single transactions were recorded.

The two largest transactions were performed in 2010 in the village of Jarużyn (Osielsko commune) neighbouring on Bydgoszcz. In both cases the lots exceeded 90 ha, and despite this highly advantageous location, their market value was very low, at $0.65-1.22$ zlotys per $\mathrm{m}^{2}$. Because of its location, the village will probably undergo intensive urbanisation processes in the nearest future. It has good transport links with the Bydgoszcz centre; besides, residential construction in the city's Fordon quarter expands in its direction.

What corroborates the above reflections is the spatial distribution of the basic parameters of transactions in agricultural land: the average size of lots and their market value (Fig. 3).

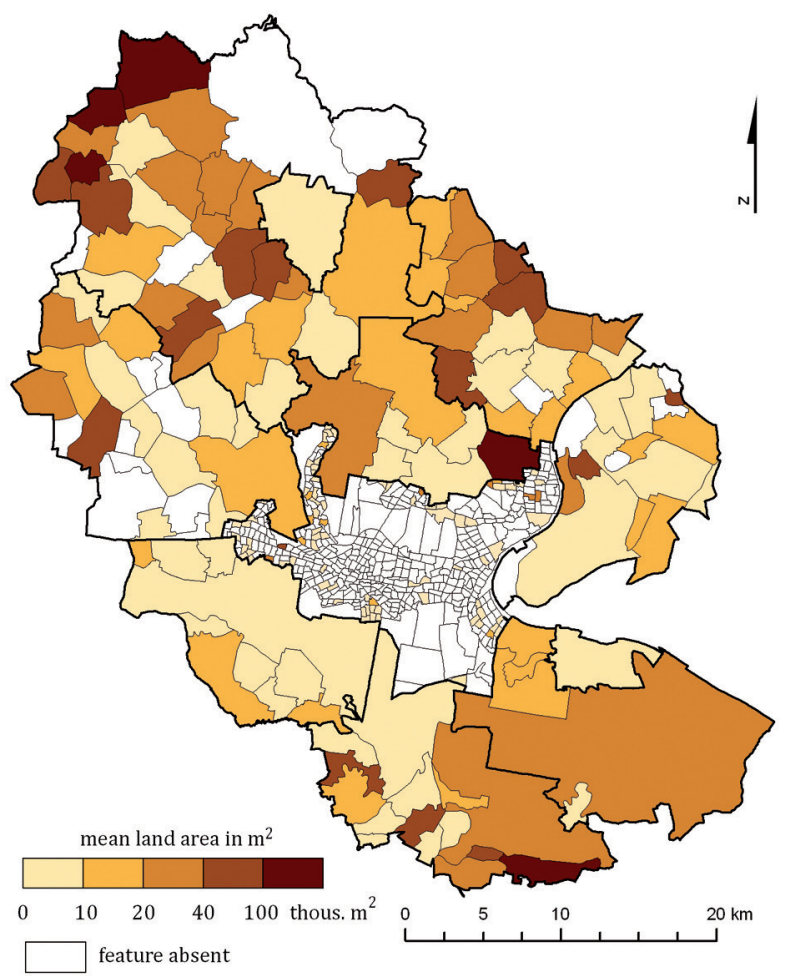

The greatest average size of lots in single transactions was recorded in units located in the northern part of the poviat, which still has substantial resources of Treasury (formerly statefarm) agricultural land. It was mainly bought by natural persons to enlarge their farms. As has already been mentioned, the leader here was Koronowo commune, especially its villages of Dziedzinek, Mąkowarsko and Osie, in which the mean area of lots sold exceeded 20-30 ha. In single cases those figures were even higher. The situation was similar in some villages in the southern part of Nowa Wieś Wielka commune, but here the average size of lots as a rule did not exceeded 10 ha. The only exception was a transaction concluded in the village of Dąbrowa Wielka where the land exceeded 50 ha.

In turn, transactions involving the smallest lots were performed in the communes neighbouring on Bydgoszcz. Here the average size of agricultural land sold as a rule did not exceeded 1 ha, the only exception being the above-mentioned transactions in the village of Jarużyn.

The spatial distribution of the market value of farmland traded looks quite different. It attained the highest prices in the communes surrounding Bydgoszcz, especially Białe Błota, Osielsko and

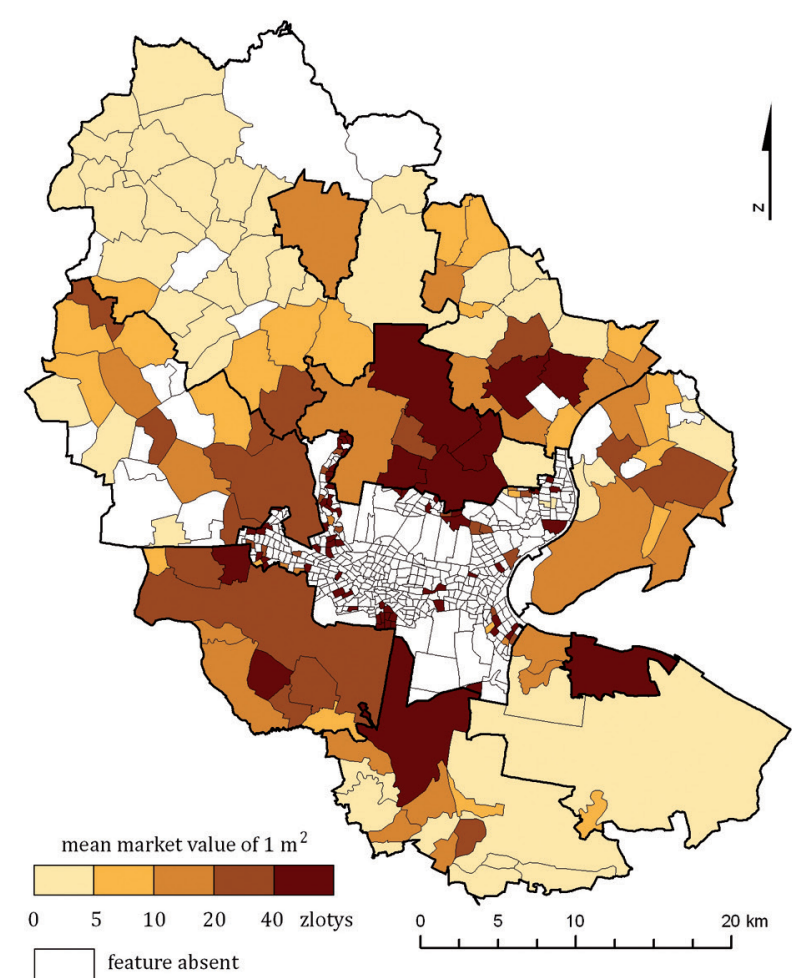

Fig. 3. Transactions in agricultural land over the years 2007-2010. 
Nowa Wieś Wielka. Those were usually small vacant lots the area of which suggests that shortly after the change of ownership they would also change their purpose.

Out of the 69 transactions concluded between 2007 and 2010 in which the market price of agricultural land was the highest (over 200 zlotys per $\mathrm{m}^{2}$ ), as many as 49 were made in Osielsko commune, including 31 in its village of Niemcz. In this village farmland prices were the highest in the entire poviat and in the entire study period, in some transactions exceeding 1,000 zlotys per $\mathrm{m}^{2}$. What played a substantial role in boosting the price of unbuilt agricultural land was the demand resulting from the very favourable location of the lots with respect to Bydgoszcz. However, even though farmland prices attained very high levels in this commune, when all transactions are taken into consideration the mean price of $1 \mathrm{~m}^{2}$ was a mere 34 zlotys. This lowering of the value was due to the already mentioned two large-lot transactions in the village of Jarużyn.

In terms of the number of sale/purchase transactions in agricultural land, Osielsko commune was exceeded by Białe Błota commune, but the prices attained in the latter were lower, comparable in only a few cases. This was undoubtedly due to differences in the natural conditions of the communes. The former lies on the Świecie Upland, the other occupies a low-lying western fragment of the Torun Basin. The settlements located here are wedged between the Noteć valley in the south and the Bydgoszcz Canal depression in the north.

Worth noting are also transactions in agricultural land conducted in towns. The lots were small, but attaining relatively high prices over the study period. This especially concerns Solec Kujawski, where the market value of $1 \mathrm{~m}^{2}$ exceeded 200 zlotys in single transactions. In the town of Koronowo farmland prices were lower.

As has already been mentioned, the lowest prices of farmland were recorded in large-lot, agriculturally oriented transactions, hence they mainly took place in the north-western part of the poviat. Similarly low prices could be found on the opposite side of the poviat, in its south-eastern part. Here, however, the poor demand was caused by its high woodiness and poor transport links with Bydgoszcz, as well as by spatial development plans for it. Over the entire study period, in the villages with the biggest supply of farmland - Przyłubie (Solec Kujawski commune) and Leszyce (Nowa Wieś Wielka commune) - 8 transactions were conducted for a total area of 68 ha, of which 60 ha were sold in 2007 in two transactions.

\section{Transactions in unbuilt land}

Because of its destination, this land is often additionally described as 'urbanised' or 'construction' lots to differentiate it from agricultural land. In terms of the number of transactions concluded, it only comes second to agricultural land. Over the years 2007-2010, a total of 725 such transactions were made in Bydgoszcz poviat, of which 561 in rural areas. The lots involved were small, although in the rural areas their average size was greater (Table 3). The only outstanding commune in this respect was Dobrcz, where the average was several times higher than in the remaining communes, but it still did not exceed 7,500 $\mathrm{m}^{2}$.

Over the years 2007-2010, the majority of transactions in unbuilt land were performed in the rural communes of Białe Błota, Nowa Wieś Wielka and Koronowo, as well as in the town of Koronowo: $89.9 \%$ of all transactions in this category of land (Table 3).

Worth noting is the fact that in the rural commune of Solec Kujawski there was no unbuilt land on offer at all, while in Osielsko commune only a single transaction was concluded. In the latter case this is surprising, because the commune is highly active on the market of farmland and built-up land. Presumably, owners of this kind of land treat it as a short-term capital investment, or think that its sale will be more profitable after they have built single-family houses on the lots. This can be indicated by the number of offers of lots with fully equipped new houses, or houses in the rough.

The heavily forested Solec Kujawski commune, which is also partly situated on the Vistula floodplain, has no major land resources of interest to potential investors. Its share in the land market was only limited to agricultural land. However, the town of Solec Kujawski itself was slightly more active on the market: here 6 transactions were made for land for various purposes. 
Table 3. Transactions in unbuilt land in Bydgoszcz poviat over the years 2007-2010.

\begin{tabular}{|c|c|c|c|c|c|c|c|c|}
\hline \multirow{2}{*}{ Towns, communes } & \multicolumn{2}{|c|}{ Transactions } & \multicolumn{2}{|c|}{ Total market value } & \multicolumn{2}{|c|}{ Total area } & \multirow{2}{*}{$\begin{array}{c}\text { Mean size } \\
\mathbf{m}^{2}\end{array}$} & \multirow{2}{*}{$\begin{array}{c}\text { Mean price } \\
\text { zlotys } / \mathrm{m}^{2}\end{array}$} \\
\hline & number & $\%$ & $\begin{array}{l}\text { thous. } \\
\text { zlotys }\end{array}$ & $\%$ & thous. $\mathrm{m}^{2}$ & $\%$ & & \\
\hline Bydgoszcz poviat & 725 & 100.0 & 68,300 & 100.0 & 1,447 & 100.0 & 1,995 & 47 \\
\hline Towns, of which: & 164 & 22.6 & 8,314 & 12.2 & 193 & 13.4 & 1,179 & 43 \\
\hline Koronowo, town & 158 & 21.8 & 8,127 & 11.9 & 191 & 13.2 & 1,206 & 43 \\
\hline Solec Kuj., town & 6 & 0.8 & 187 & 0.3 & 3 & 0.2 & 486 & 64 \\
\hline Rural communes & 561 & 77.4 & 59,986 & 87.8 & 1,253 & 86.6 & 2,234 & 48 \\
\hline Białe Błota & 172 & 23.7 & 26,655 & 39.0 & 174 & 12.0 & 1,009 & 154 \\
\hline Dąbrowa Chełm. & 11 & 1.5 & 751 & 1.1 & 27 & 1.8 & 2,426 & 28 \\
\hline Dobrcz & 47 & 6.5 & 6,676 & 9.8 & 339 & 23.5 & 7,223 & 20 \\
\hline Koronowo & 149 & 20.6 & 8,672 & 12.7 & 251 & 17.3 & 1,683 & 35 \\
\hline Nowa Wieś Wlk. & 167 & 23.0 & 14,153 & 20.7 & 439 & 30.3 & 2,627 & 32 \\
\hline Osielsko & 1 & 0.1 & 640 & 0.9 & 1 & 0.1 & 881 & 726 \\
\hline Sicienko & 14 & 1.9 & 2,439 & 3.6 & 23 & 1.6 & 1,645 & 106 \\
\hline Solec Kujawski & 0 & 0.0 & 0 & 0.0 & 0 & 0.0 & 0 & 0 \\
\hline
\end{tabular}

Source: see Table 2

Over the study period, the greatest number of transactions concerning unbuilt land were contracted in the town and rural commune of Koronowo, at $307(42.4 \%)$. Interest in vacant land in those units largely followed from their resources of land and attractive geographical environment, with a diversified relief, extensive forest complexes, the enchanting Brda valley, and a multitude of natural lakes. The attractiveness of this area was enhanced after a reservoir had been built here in 1961, known as Lake Koronowo. It was constructed by the damming of the Brda river, and for its basin use was made of a depression containing a sequence of postglacial lakes. Besides, this area has good transport links with Bydgoszcz. The sum total of those qualities has made it a very attractive recreation area for both, tourists and residents. Hence the unbuilt land bought here was mostly intended for recreational construction, in accordance with the local development plans, and less often for residential purposes. Often objects of transactions were lots belonging to the many recreation centres that had been greatly demolished when left without suitable protection after the systemic transformation of the 1990s.

In the remaining communes the unbuilt land was usually bought for residential purposes and in order to conduct an economic activity, mainly services. This is especially readily visible in Białe Błota and Nowa Wieś Wielka, both situated in the direct vicinity of Bydgoszcz (Fig. 4).
In a spatial approach, transactions in unbuilt land display marked regularities. In areas neighbouring on the city where urbanisation processes are highly advanced, the lots sold/bought were usually small, but their market prices attained the highest values (Fig. 3). Hence in the villages of Białe Błota and Brzoza (Nowa Wieś Wielka commune) the average price of $1 \mathrm{~m}^{2}$ of this land category as a rule oscillated around 200 zlotys. In single transactions performed in those communes the price of $1 \mathrm{~m}^{2}$ even exceeded 500 zlotys, and in the village of Niemcz (Osielsko commune), even 720 zlotys.

The prices for this category of land looked different in areas of great natural beauty and where local plans allow the development of production services. Usually they are situated peripherally with respect to Bydgoszcz. Here the vacant lots traded were larger, but their prices lower. This holds especially for transactions performed in the rural areas of Koronowo commune, where land earmarked for leisure and recreational purposes was in great demand. In turn, in Białe Błota, Nowa Wieś Wielka and Dąbrowa Chełmińska communes interest in unbuilt land followed from a great demand for lots intended for single-family residential construction, often connected with the development of service functions (Fig. 4).

Worth noting in this category of land are the many transactions involving lots that were planned to be used in the modernisation of public roads. Those were small lots, and their market 

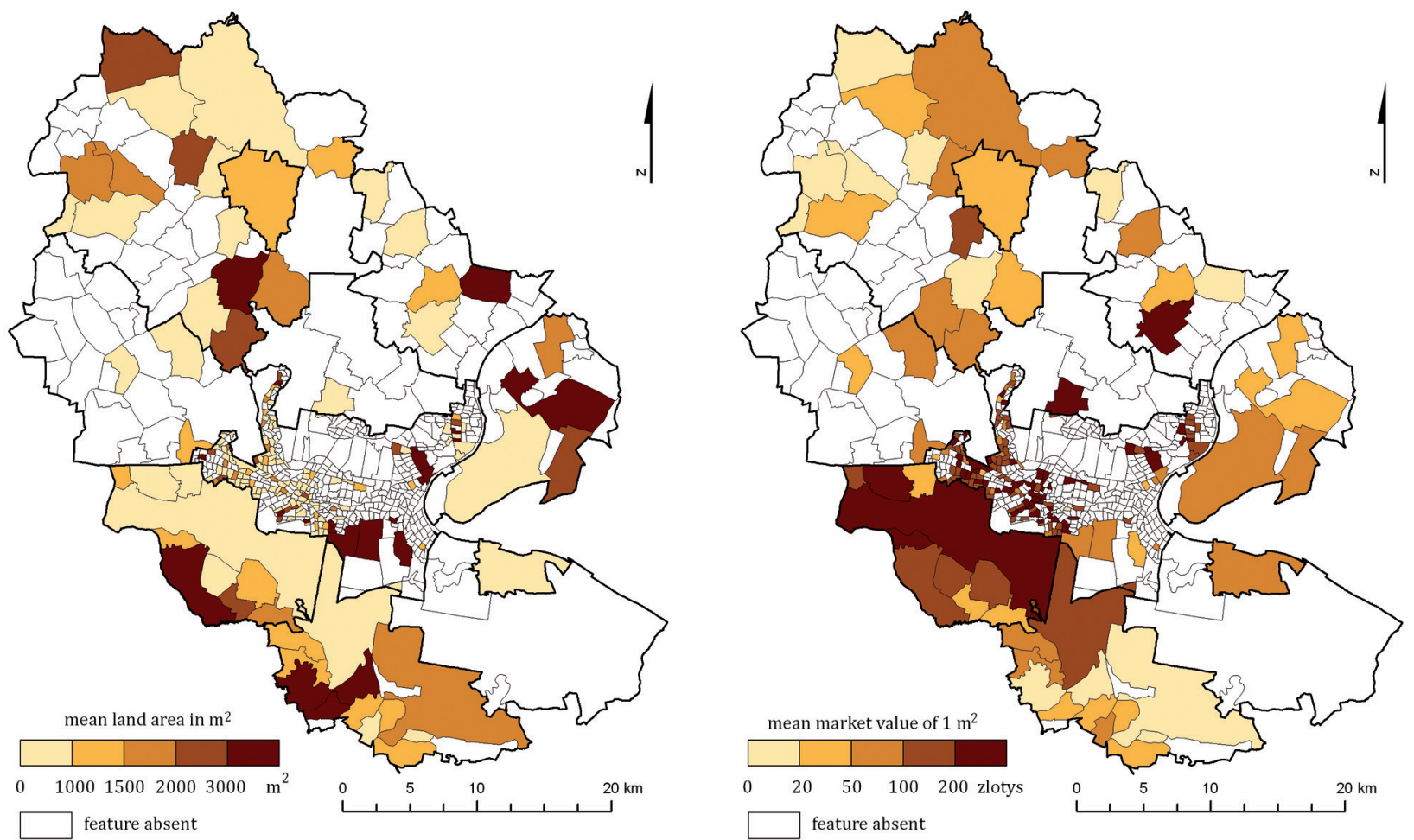

Fig. 4. Transactions in unbuilt land over the years 2007-2010.

value often fell under 1 zloty per $1 \mathrm{~m}^{2}$. A characteristic feature of those transactions was their spatial scatter.

\section{Transactions in built-up land}

Over the study period, the fewest transactions were those in built-up land carrying residential buildings. Their number amounted to 590, but the total market value of those lots was much higher than that of the other kinds, at 214.6 million zlotys (Table 4 ).

The demand for this type of land was the heaviest in Białe Błota and Osielsko communes directly neighbouring on Bydgoszcz. Here it therefore attained the highest market value in the entire suburban zone: from an average of 390 zlotys per $\mathrm{m}^{2}$ in Białe Błota to 426 zlotys in Osielsko. Built-up land fetched similarly high prices in the town of Koronowo. In the remaining communes the market value of $1 \mathrm{~m}^{2}$ of built-up land did not exceed 300 zlotys.

The cheapest built-up lots could be found in Sicienko commune, where their average market value in the three transactions concluded there was a mere 107 zlotys. The reasons for such a low demand for non-agricultural land in this commune have been presented earlier. Not a single transaction in this kind of land was concluded in the rural Solec Kujawski commune, of low settlement attractiveness.

It is also worth noting that the average prices of built-up land were higher in rural areas and lower in towns. In the case of residential buildings, this was principally due to the wish of individual buyers to improve their living conditions. Similar tendencies could be found in the purchase of lots combining the residential function with that of production services. This is corroborated by the great number of transactions in this kind of land in the two rural communes mentioned earlier (Białe Błota and Osielsko, Table 4) that also fetched high prices.

As an analysis of transactions in built-up land showed, their objects were usually lots with newly built, uninhabited, single-family or semi-detached houses. Their standards differed, from a rough state to full equipment. They also differed in architecture, rarely adjusted to the traditional rural design. The earlier architecture also disappeared when the farm buildings bought required 
Table 4. Transactions in built-up land in Bydgoszcz poviat over the years 2007-2010.

\begin{tabular}{|c|c|c|c|c|c|c|c|c|}
\hline \multirow{2}{*}{ Towns, communes } & \multicolumn{2}{|c|}{ Transactions, total } & \multicolumn{2}{|c|}{ Total market value } & \multicolumn{2}{|c|}{ Total area } & \multirow{2}{*}{$\begin{array}{c}\text { Mean size } \\
\mathbf{m}^{2}\end{array}$} & \multirow{2}{*}{$\begin{array}{c}\text { Mean price } \\
\text { zlotys } / \mathrm{m}^{2}\end{array}$} \\
\hline & number & $\%$ & $\begin{array}{l}\text { thous. } \\
\text { zlotys }\end{array}$ & $\%$ & thous. $\mathrm{m}^{2}$ & $\%$ & & \\
\hline Bydgoszcz poviat & 590 & 100.0 & 214,614 & 100.0 & 705 & 100.0 & 1,195 & 304 \\
\hline Towns, of which: & 91 & 15.4 & 23,340 & 10.9 & 89 & 12.6 & 975 & 263 \\
\hline Koronowo, town & 57 & 15.4 & 16,262 & 7.6 & 39 & 5.5 & 691 & 413 \\
\hline Solec Kuj., town & 34 & 15.4 & 7,078 & 3.3 & 49 & 7.0 & 1,451 & 143 \\
\hline Rural communes & 499 & 15.4 & 191,274 & 89.1 & 616 & 87.4 & 1,235 & 310 \\
\hline Białe Błota & 208 & 35.3 & 69,791 & 32.5 & 179 & 25.4 & 861 & 390 \\
\hline Dąbrowa Chełm. & 55 & 9.3 & 20,944 & 9.8 & 109 & 15.5 & 1,984 & 192 \\
\hline Dobrcz & 29 & 4.9 & 4,454 & 2.1 & 27 & 3.8 & 932 & 165 \\
\hline Koronowo & 32 & 5.4 & 12,747 & 5.9 & 76 & 10.8 & 2,360 & 169 \\
\hline Nowa Wieś Wlk. & 63 & 10.7 & 22,462 & 10.5 & 78 & 11.1 & 1,237 & 288 \\
\hline Osielsko & 109 & 18.5 & 60,186 & 28.0 & 141 & 20.0 & 1,296 & 426 \\
\hline Sicienko & 3 & 0.5 & 690 & 0.3 & 7 & 1.0 & 2,152 & 107 \\
\hline Solec Kujawski & 0 & 0.0 & 0 & 0.0 & 0 & 0.0 & 0 & 0 \\
\hline
\end{tabular}

Source: see Table 2.

modernisation or a major overhaul because of their poor state of repair.

Transactions in built-up land also took place around Bydgoszcz. Worth noting is an active part played in them by communes situated farther from the city centre, e.g. Dąbrowa Chełminska commune, separated from the rest of the poviat by the Vistula valley. Standing out in this commune is the village of Ostromecko, closest to Bydgoszcz and separated from it by the Vistula, but having good transport connections with the city via a road-and-railway bridge. Here 47 sale/purchase transactions were concluded over the study period, most of them (43) in the years 2007-2008. The lots involved were small, but the market value of their square metre ranged between 200 and 400 zlotys. By contrast, in the other villages of the commune a mere 8 transactions were concluded.

But the leading role on the market of builtup land in the suburban zone of Bydgoszcz was played by the already mentioned communes of Białe Błota and Osielsko. Here a total of 317 transactions of this type were conducted, while prices of $1 \mathrm{~m}^{2}$ were the highest (Fig. 5). In more than 20 transactions the market value of land exceeded 1,000 zlotys per $\mathrm{m}^{2}$, a maximum being reached in a 2010 transaction concluded in the village of Osielsko $-2,640$ zlotys. The high prices of builtup lots were a result of their favourable location and standard (level of development, physical infrastructure, etc.). Less popular were lots with old buildings requiring major repairs and modernisation, or earmarked for demolition.

High prices for built-up land were also recorded in a few transactions conducted in the towns of Koronowo and Solec Kujawski. Those were usually lots with multi-family houses.

There was also greater interest in built-up land in villages situated along a major road connecting Bydgoszcz with Chojnice (DK 25) and its branch going to Koronowo (DK 56). It fetched high prices in the village of Sokole Kuźnica, which is situated on the Koronowo Lagoon. In two transactions concluded here in 2010 the market value of $1 \mathrm{~m}^{2}$ exceeded 550 zlotys.

\section{Transactions in recreational land}

Generally, transactions in land intended for recreational purposes have a highly specific character. The lots concerned mainly cluster in areas of great natural beauty (Motek 2009). In the study area, most transactions of this kind involved land surrounding the Koronowo Lagoon, attractive in recreational terms because of its natural features. The transactions made here concerned almost exclusively land intended for recreation purposes. Sometimes the objects of trade were entire former tourist and recreation centres built before the systemic change of 1989. As has already been mentioned, having often lost the old hosts, they had gradually deteriorated and their buildings suf- 

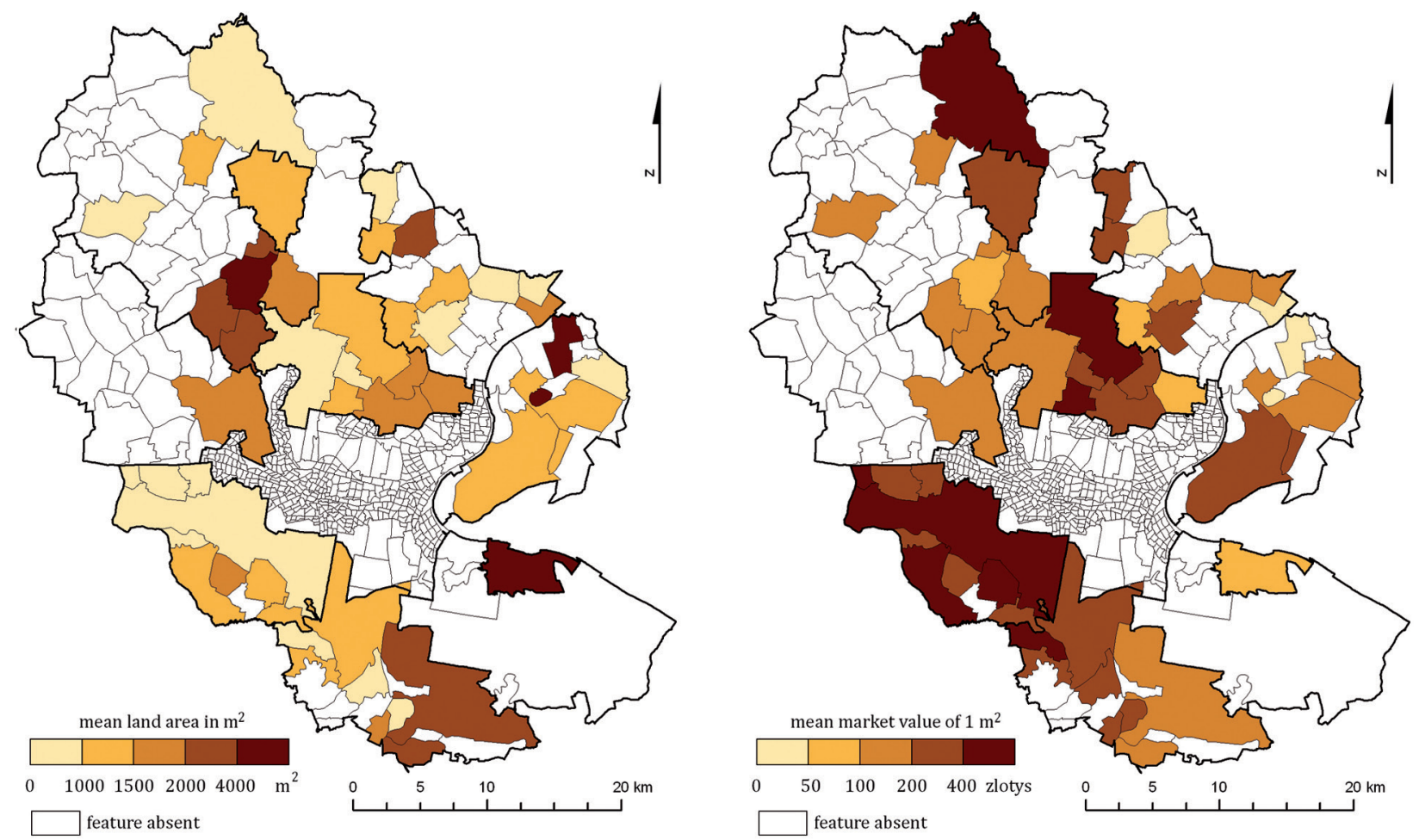

Fig. 5. Transactions in built-up land over the years 2007-2010.

fered almost complete depreciation. Hence the average market value of this land was the lowest in the study area, at 10.33 zlotys per $\mathrm{m}^{2}$. The new owners of the old recreation centres as a rule divided them into smaller lots which they then sold, one by one, to successive - final - buyers.

Because of the tourist attractiveness of the town and commune of Koronowo, those units accounted for $84.5 \%$ of transactions carried out over the years 2007-2010 in this category of land in the entire Bydgoszcz poviat (Table 5). In the remaining area the number of transactions varied between 1 and 5 . The market price of $1 \mathrm{~m}^{2}$ of land differed and depended not only on the attractiveness of its location, but also on its state of development. The highest price was quoted in

Table 5. Transactions in recreational land in Bydgoszcz poviat over the years 2007-2010

\begin{tabular}{|c|c|c|c|c|c|c|c|c|}
\hline \multirow{3}{*}{ Towns, communes } & \multirow{2}{*}{\multicolumn{2}{|c|}{ Transactions }} & \multirow{2}{*}{\multicolumn{3}{|c|}{ Total market value }} & \multicolumn{3}{|c|}{ Ares } \\
\hline & & & & & & \multicolumn{2}{|c|}{ total } & \multirow{2}{*}{$\begin{array}{c}\text { mean } \\
\mathrm{m}^{2}\end{array}$} \\
\hline & number & $\%$ & $\begin{array}{l}\text { thous. } \\
\text { zlotys }\end{array}$ & $\%$ & zlotys $/ \mathrm{m}^{2}$ & thous. $\mathrm{m}^{2}$ & $\%$ & \\
\hline Bydgoszcz poviat & 90 & 100.0 & $\mathbf{1 7 1 7 4 . 8}$ & 100.0 & 21.55 & 797.3 & 100.0 & 8858.5 \\
\hline Towns, of which: & 72 & 80.0 & 14410.7 & 92.9 & 18.79 & 766.5 & 96.2 & 10645.5 \\
\hline Koronowo, town & 70 & 77.8 & 7873.0 & 45.8 & 10.33 & 761.9 & 95.6 & 10884.0 \\
\hline Solec Kuj., town & 2 & 2.2 & 6537.7 & 38.1 & 1307.60 & 4.6 & 0.6 & 2298.0 \\
\hline Rural communes: & 18 & 20.0 & 2764.1 & 16.1 & 30.80 & 30.8 & 89.75 & 1710.9 \\
\hline Białe Błota & 1 & 1.1 & 3.4 & 0.0 & 39.47 & 0.1 & 0.0 & 76.0 \\
\hline Dąbrowa Chełm. & 1 & 1.1 & 650.0 & 3.8 & 216.67 & 3.3 & 0.4 & 3300.0 \\
\hline Dobrcz & 1 & 1.1 & 32.5 & 0.2 & 16.50 & 1.9 & 0.2 & 1933.0 \\
\hline Koronowo & 6 & 6.7 & 1177.6 & 6.9 & 84.14 & 14.3 & 1.8 & 2387.8 \\
\hline Nowa Wieś Wlk. & 5 & 5.6 & 388.5 & 2.3 & 129.67 & 3.4 & 0.4 & 678.8 \\
\hline Osielsko & 3 & 3.3 & 425.0 & 2.5 & 60.71 & 7.4 & 0.9 & 2455.7 \\
\hline Sicienko & 1 & 1.1 & 87.0 & 0.5 & 218.05 & 0.4 & 0.1 & 399.0 \\
\hline Solec Kujawski & 0 & 0.0 & 0.0 & 0.0 & 0.00 & 0.0 & 0.0 & 0.0 \\
\hline
\end{tabular}


the sale/purchase of a hotel-and-training facility in the town of Solec Kujawski, built in 2008. As a rule, the average area of a single recreation lot did not exceed 3,000 $\mathrm{m}^{2}$. Only in the town of Koronowo, where entire former tourist-and-leisure centres were sold, were the lots larger (Table 5).

\section{Final remarks}

The suburban zone of Bydgoszcz has substantial resources of farmland intended for sale, hence its proportion in total land turnover is the greatest. The chief sources of farmland supply are the Treasury and individually operated agricultural holdings. In the former case, the aim is rational development of the land possessed, while entities involved in the latter case are farms that have to wind up their activity for a variety of reasons.

After the ownership rights have been transferred, as a rule there is a change in the use of the farmland traded. Hence lots of this kind greatly affect the land-use pattern in the suburban zone of Bydgoszcz, as expressed, e.g., by a high proportion of lots of up to 1 ha in the areas neighbouring on Bydgoszcz.

As a result of such transactions and changes introduced by the new owners in the use of the land they bought, former villages start to transform into highly urbanised settlements with a declining agricultural function. An example is villages situated in the communes of Białe Błota and Osielsko. In the remaining communes one can already observe the beginnings of such settlements, too. This is also corroborated by the spatial distribution of transactions in built and vacant lots. In the case of farmland, those were usually small lots, up to $3,000 \mathrm{~m}^{2}$, which suggests that they could be intended for single-family housing, especially if the lots were in areas neighbouring on Bydgoszcz.

A specific feature of farmland transactions was a small proportion of large deals concerning land earmarked for agricultural purposes. They were usually concluded in the peripheries of the study area where the resources of Treasury-owned farmland were big and spatial development plans did not foresee any change in its use. Those are also areas poorly accessible by transport.
The problems that Bydgoszcz encounters in its spatial development owing to its natural conditions significantly affect transactions in land in the suburban zone. They have determined the directions of the city's expansion. Those are ribbons going beyond its administrative limits along the already existing transport routes.

The land market in the suburban zone of Bydgoszcz, local in character, responded to the world economic crisis in a readily visible way. There was a clear drop in the number of transactions conducted after 2007 and in their market value. But its effect on the price of $1 \mathrm{~m}^{2}$ of land was negligible. An exception was built-up lots in 2009 - the worst year for land transactions. They reached the highest average market value in the entire study period - 372 zlotys for $1 \mathrm{~m}^{2}$. In the remaining years this figure ranged from 234 zlotys in 2007 to 316 zlotys in 2010.

Translated by Maria Kawińska

\section{References}

Brzeski W.J., Cichoń D., Jurek K., Rogatko B., 2008. Nieruchomości w Polsce. Pośrednictwo i zarządzanie. Kompendium (Land in Poland. Intermediation and management. A compendium). Europejski Instytut Nieruchomości, Warszawa-Kraków.

Cymerman R., Hopfer I., 2005. Wycena nieruchomości. Zasady $i$ procedury (Land appraisal. Rules and procedures). Warszawa.

Głębocki B., 2011. Rynek nieruchomości gruntowych w Bydgoszczy - zasoby i wielkość obrotów w latach 2007-2009 (Land market in Bydgoszcz - resources and volume of transactions in the years 2007-2009). In: Marciniak K., Sikora K., Sokołowski D. (eds), Koncepcje i problemy badawcze geografii. Wydawnictwo Uczelniane Wyższej Szkoły Gospodarki w Bydgoszczy. Bydgoszcz: 345-361. ISBN 978-83-61036-15-9.

Hozer J. (ed.), 2006. Wycena nieruchomości (Land valuation). Szczecin.

Jakóbczyk-Gryszkiewicz J., 2009. Tendencje przestrzenne w ksztattowaniu cen ziemi w Polsce po 1990 r. (Spatial tendencies in land prices in Poland after 1990). Wydawnictwo Uniwersytetu Łódzkiego, Łódź.

Kałkowski L. (ed.), 2003. Rynek nieruchomości w Polsce (The land market in Poland). Twigger, Warszawa.

Kondracki J., 1994. Geografia Polski. Mezoregiony fizycznogeograficzne (Geography of Poland. Physical-geographic mesoregions). Wydawnictwo Naukowe PWN, Warszawa.

Kondracki J., 2009. Geografia regionalna Polski (Regional geography of Poland). Wydawnictwo Naukowe PWN, Warszawa. 
Kucharska-Stasiak E., 1999. Nieruchomość a rynek (Real estate and the market). Wydawnictwo Naukowe PWN, Warszawa.

Kucharska-Stasiak E., 2001. Wartość rynkowa nieruchomości (The market value of land). Twigger, Warszawa.

Maćkiewicz B., 2007. Rynek nieruchomości niezabudowanych $w$ Poznaniu i powiecie poznańskim w latach 1995-2000 (The market in unbuilt land in Poznań and Poznań poviat over the years 1995-2000). Bogucki Wydawnictwo Naukowe, Poznań.

Motek P., 2009. Wielkość rynku nieruchomości niezabudowanych $\mathrm{w}$ powiecie puławskim $\mathrm{w}$ latach 1995-2004 (Trading volume of unbuilt land in Puławy poviat over the years 1995-2004). In: Kacprzak E., Maćkiewicz B., Motek P. (eds), Uwarunkowania i rozwój rynku nieruchomości niezabudowanych na obszarach atrakcyjnych turystycznie w powiecie puławskim. Bogucki Wydawnictwo Naukowe, Poznań: 99-112.

Niemczyk R., 2002. Gospodarka nieruchomościami a kwestia katastru (Land management and the cadaster question). Biblioteka Menedżera i Służby Pracowniczej, Bydgoszcz. Źróbek S., Źróbek R., Kuryj J., 2008. Gospodarka nieruchomościami z komentarzem do wybranych procedur (Land management, with a commentary to selected procedures). Wydawnictwo Gall, Katowice. 